Louisiana State University

LSU Digital Commons

6-1-2006

\title{
Do geese fully develop brood patches? A histological analysis of lesser snow geese (Chen caerulescens caerulescens) and Ross's geese (C. rossii)
}

\author{
Jón Einar Jónsson \\ Louisiana State University \\ Alan D. Afton \\ Louisiana State University \\ Dominique G. Homberger \\ Louisiana State University \\ William G. Henk \\ School of Veterinary Medicine \\ Ray T. Alisauskas \\ Environment Canada
}

Follow this and additional works at: https://digitalcommons.Isu.edu/biosci_pubs

\section{Recommended Citation}

Jónsson, J., Afton, A., Homberger, D., Henk, W., \& Alisauskas, R. (2006). Do geese fully develop brood patches? A histological analysis of lesser snow geese (Chen caerulescens caerulescens) and Ross's geese (C. rossii). Journal of Comparative Physiology B: Biochemical, Systemic, and Environmental Physiology, 176 (5), 453-462. https://doi.org/10.1007/s00360-006-0066-y 
Jón Einar Jónsson · Alan D. Afton · Dominique G.

Homberger • William G. Henk • Ray T. Alisauskas

\section{Do geese fully develop brood patches? A histological analysis of lesser snow geese (Chen caerulescens caerulescens) and Ross's geese (C. rossit)}

Received: 8 June 2005/ Revised: 16 December 2005 / Accepted: 23 December 2005/Published online: 24 January 2006

(C) Springer-Verlag 2006

\begin{abstract}
Most birds develop brood patches before incubation; epidermis and dermis in the brood patch region thicken, and the dermal connective tissue becomes increasingly vascularized and infiltrated by leukocytes. However, current dogma states that waterfowl incubate without modifications of skin within the brood patch region. The incubation periods of lesser snow geese (Chen caerulescens caerulescens; hereafter called snow geese) and Ross's geese (C. rossii) are 2-6 days shorter than those of other goose species; only females incubate. Thus, we hypothesized that such short incubation periods would require fully developed brood patches for sufficient heat transfer from incubating parents to eggs. We tested this hypothesis by analyzing the skin histology of abdominal regions of snow and Ross's geese collected at Karrak Lake, Nunavut, Canada. For female snow geese, we found that epidermis
\end{abstract}

Communicated by H.V. Carey

Jón Einar Jónsson

School of Renewable Natural Resources, Louisiana State University, Baton Rouge, LA 70803, USA

\section{A. D. Afton}

United States Geological Survey, Louisiana Cooperative Fish and Wildlife Research Unit, Louisiana State University, Baton Rouge, LA 70803, USA

D. G. Homberger

Department of Biological Sciences,

Louisiana State University, Baton Rouge, LA 70803, USA

W. G. Henk

Department of Comparative Biomedical Sciences, School of Veterinary Medicine,

Louisiana State University, Baton Rouge, LA 70803, USA

R. T. Alisauskas

Canadian Wildlife Service, 115 Perimeter Road, 57N 0X4, Saskatoon, SK, Canada

Jón Einar Jónsson $(\square)$

Háaleitisbraut 17, 108, Reykjavík, Iceland

E-mail: joneinar@hive.is and dermis had thickened and vascularization of dermis was 14 times greater, on average, than that observed in males ( $n=5$ pairs). Our results for Ross's geese $(n=5$ pairs) were more variable, wherein only one of five female Ross's geese fully developed a brood patch. Our results are consistent with three hypotheses about brood patch development and its relationship with different energetic cost-benefit relationships, resulting from differences in embryonic development and body size.

Keywords Body size Brood patch - Geese · Histology $\cdot$ Incubation

\section{Introduction}

In most birds, parents develop brood patches (i.e., incubation patches) in preparation for incubation (Drent 1975; Wiebe and Bortolotti 1993; Lea and Klandorf 2002). The skin (i.e., epidermis, dermis, and subcutis) of brood patches is modified to enhance heat transfer from incubating parents to eggs (Jones 1971; Gill 1995; Lea and Klandorf 2002): (1) the epidermis of the brood patch becomes $2-5 \times$ thicker than that in nonbreeding birds, which protects the skin from injury, (2) the dermal connective tissue (hereafter called connective tissue) is infiltrated by leukocytes, thickens, and becomes more pliable to enhance contact between skin and eggs, (3) blood vessels in the dermis increase in number and diameter, which improves heat transfer from skin to eggs (see also Midtgård et al. 1985), and (4) dermal fat, dermal musculature, and feather follicles are reduced. Furthermore, feathers are shed from the thoraco-abdominal region (hereafter called brood patch region), resulting in a bare area of skin in direct contact with eggs.

In this paper, the term skin refers collectively to epidermis, dermis, and subcutaneous fat. We define fully developed brood patches as those that undergo epidermal thickening, enhanced vascularization of the dermis, and 
thickening of connective tissue with an associated leukocyte infiltration (Jones 1971; Lea and Klandorf 2002). The term brood patch development is restricted to processes that involve any of these changes. The formation of a defeathered ventral area is associated with brood patch development (Bailey 1952; Hanson 1959; Jones 1971; Lea and Klandorf 2002), but may occur without other modifications of the brood patch skin and is, thus, distinguished from full brood patch development in the narrow sense. The term incompletely developed brood patches indicates individuals that lack one or more of the modifications associated with brood patch development in any combination and to any degree of completion (see reviews by Jones 1971; and Lea and Klandorf 2002). The term variable brood patch development indicates a species that sometimes fully develops brood patches, incompletely developed brood patches, or no brood patches at all.

Ostriches (Struthio camelus) and other ratites, some species of alcids (Alcidae), and waterfowl (Anseriformes) apparently incubate without some or any histological modifications to their brood patch regions (Jones 1971; Gill 1995; Lea and Klandorf 2002; McFarlane Tranquilla et al. 2003). Cassin's auklets (Ptychoramphus aleuticus) often incubate with only incompletely developed brood patches, which do not consistently show bare skin and thickened epidermis or thickened connective tissue (Manuwal 1974; see also McFarlane Tranquilla et al. 2003). Furthermore, bareskinned brood patches in Cassin's auklets sometimes are re-feathered at mid-incubation and are not maintained for re-nesting attempts; parents that incubate late in the breeding season often do not develop any brood patches at all (Manuwal 1974). Similar variation in brood patch development was observed in the related marbled murrelet (Brachyramphus marmoratus) (McFarlane Tranquilla et al. 2003).

Only females incubate in most waterfowl species (Afton and Paulus 1992). Female ducks and geese pluck feathers from their brood patch regions to line their nests; the formation of this defeathered ventral area does not necessarily entail full brood patch development (Bailey 1952; Hanson 1959; Jones 1971; Cole 1979; Afton and Paulus 1992; Lea and Klandorf 2002; see also Dorst 1975; Welty and Baptista 1988; Gill 1995). Current dogma states that the defeathered ventral area in waterfowl is not otherwise modified before incubation to enhance heat transfer (Bailey 1952; Dorst 1975; Gill 1995; Lea and Klandorf 2002). However, in black-bellied whistling ducks (Dendrocygna autumnalis), in which both sexes incubate, vascularization of the brood patch region of both sexes increases in preparation for incubation (Rylander et al. 1980; Afton and Paulus 1992).

The rate of heat loss increases in birds with decreasing body size, because a small animal has a relatively greater surface area facing environmental stimuli while having a relatively lower tissue volume generating body heat (Calder 1996; Schmidt-Nielsen 1997). This relationship is not linear throughout all bird families, because heat conductance is not just a function of surface area but also depends on the shape and morphology of animals (Calder 1996; SchmidtNielsen 1997). This regional heterothermy occurs in all endothermic animals in environments colder than the animals' core temperature; thus, there is always a zone of intermediate temperatures at the interface between bodies with differing temperatures. Furthermore, small passerine birds in cold environments compensate for small size by decreasing temperature in peripheral tissues while maintaining a stable core temperature, thereby decreasing heat exchange with ambient air to conserve energy (Schmidt-Nielsen 1997). Some passerines can also apparently conserve energy by dropping core temperature as well as peripheral temperatures (Reinertsen and Haftorn 1986).

Payne (1966) suggested that within alcids, smaller species benefit from not developing a brood patch because the unfeathered brood patch region might cause excessive heat loss during cold weather (see also Midtgård 1989). In Bantam hens (Gallus domesticus), smaller females were more sensitive to experimental cooling of the brood patch than were larger females (Brummermann and Reinertsen 1991). Mass-specific metabolic rate is greater in birds of smaller mass (Kendeigh 1970). The ability to store energy within tissues is a major contributor to fasting endurance, and larger birds can store relatively greater amounts of body fat (Calder 1996). Furthermore, larger birds lose heat at slower rates than smaller birds (Calder 1996). The Body-size Hypothesis predicts that during incubation, larger species generally have greater fasting endurances than smaller species, which compensate by relying more on foraging opportunities (Skutch 1962; Afton 1980; Thompson and Raveling 1987; Afton and Paulus 1992).

Lesser snow geese (Chen caerulescens caerulescens; hereafter called snow geese) and Ross's geese (Chen rossii) are closely related and frequently nest within the same colonies (Alisauskas and Boyd 1994; Batt et al. 1997; Weckstein et al. 2002). Ross's geese are approximately two-thirds the body size of snow geese; thus, these species often are used in comparative studies on effects of body size on behavior and physiology (MacInnes et al. 1989; Slattery and Alisauskas 1995; McCracken et al. 1997; Gloutney et al. 1999, 2001; Craig 2000; Jónsson et al. 2006). Comparisons of the two species within the same nesting colony allow observation of a natural experiment (Krebs and Davies 1993), in which phylogeny, general morphology, and temporal and environmental effects are controlled (Gloutney et al. 2001).

The incubation periods of snow and Ross's geese are 23 days, whereas those of other goose species typically last 25 or more days (Ryder 1972; Afton and Paulus 1992). This relatively short incubation period presumably is an adaptation to short Arctic summers and is achieved by maintaining high, constant egg temperatures and by minimizing temperature decreases during incubation recesses (Poussart et al. 2000). Thus, we 
hypothesized that snow geese and Ross's geese maintained these short incubation periods by fully developing brood patches; an efficient heat transfer from incubating parents to their eggs would be important for minimizing the incubation period. We tested this hypothesis by comparing the histology of the skin (i.e., epidermis and dermis) in the brood patch regions of both sexes of snow geese and Ross's geese; we assumed that male geese do not develop brood patches. Based on Payne (1966), we assumed that Ross's geese are relatively more vulnerable to heat loss through brood patches, and thus should have less developed brood patches than snow geese. Thus, we predicted that Ross's geese would have relatively thinner epidermis and connective tissue, a smaller blood vessel area, and lower leukocyte count.

Specifically, our objectives were to determine whether (1) female snow geese and Ross's geese fully develop brood patches or merely remove the feathers from the brood patch regions, and (2) the development of brood patches or patches of bare skin differ between closely related species of different body size, as previously suggested for Cassin's auklets relative to certain larger alcid species, such as razorbill (Alca torda) and puffin (Fratercula artica) (Payne 1966; but see also Manuwal 1974); and (3) determine if snow geese and/or Ross's geese show individual variability in brood patch development, like that described for alcids (Manuwal 1974; McFarlane Tranquilla et al. 2003).

\section{Materials and methods}

\section{Collection of specimens}

We collected specimens at Karrak Lake, Nunavut, Canada $\left(67^{\circ} \mathrm{N} 15^{\prime} \mathrm{N}, 100^{\circ} 15^{\prime} \mathrm{W}\right)$, from the largest goose colony within the Queen Maud Gulf Bird Sanctuary (Slattery and Alisauskas 1995; McCracken et al. 1997). The landscape at Karrak Lake is comprised of rock outcrops, sedge meadows, and tundra ponds (Slattery and Alisauskas 1995), which generally offer little shelter for incubating females and their nests (McCracken et al. 1997). Karrak Lake and its surroundings were described in detail by Ryder (1972) and McLandress (1983).

We used a .22 rifle to collect 5 breeding pairs of snow geese on 26 June 1999, and 5 breeding pairs of Ross's geese on 30 June 1999. We collected specimens of each species 4 days apart to ensure that all specimens were at about the same incubation stage because, on average, Ross's geese initiate egg-laying 4 days later than snow geese (Ryder 1972). Snow and Ross's goose pairs were shot at their nests to confirm their breeding status; all eggs were candled (Weller 1956) and we estimated that all specimens were collected on day 18 of incubation. All females were incubating four egg clutches. In 1999, the average nest initiation dates at Karrak Lake were 8 June for snow geese and 11 June for Ross's geese (R. T. Alisauskas, unpublished data); thus, the chosen collection dates were appropriate.
Hybrids between snow and Ross's geese are common (MacInnes et al. 1989; Weckstein et al. 2002). Thus, we measured fresh body mass, culmen length, total tarsus, wing length, and head length of all specimens, as defined by Dzubin and Cooch (1992). Analysis of these measurements helped to ensure that the sample did not contain individuals with phenotypic appearances of snow $\times$ Ross's geese hybrids (see MacInnes et al. 1989).

\section{Histological sections}

Immediately after collecting geese, we excised $2 \times 2 \mathrm{~cm}$ patches of skin from the appropriate ventral regions. In females, we collected skin samples from defeathered ventral areas, identified easily between the lateral pelvic apteria and caudal to the median pelvic apterium (Hanson 1959). We collected skin samples from the equivalent region of males to serve as controls. Tissue samples were placed in separate labeled vials and preserved in a solution of $10 \%$ formaldehyde for subsequent analysis.

In the lab, we processed tissue samples using the following sequence of steps: (1) feathers were cut off above the surface of skin samples, (2) skin samples were dehydrated through a series of graded alcohols, (3) tissue samples were cleared of alcohol in a solvent (xylene) that is miscible in both alcohol and paraffin wax, and (4) tissue samples were infiltrated and impregnated with paraffin wax prior to the embedding procedure. Tissue samples were embedded with the help of a Leica TP1050 Automated Vacuum Tissue Processor (Leica Microsystems Inc., Bannockburn, IL, USA). We subsequently cut sections on a microtome at the thickness of $3 \mu$ and mounted the sections on glass slides for microscopic examination. We prepared two transverse sections from each skin sample; sections were taken $1.5 \mathrm{~mm}$ from the center of each sample, which is $3 \mathrm{~mm}$ apart.

Tissue samples were stained with hematoxylin (Anatech Ltd. \#812) for cell nuclei (deep purple) and eosin-Y (Anatech Ltd. \#832) for cytoplasm (shades of pink, orange, and red). Tissue samples were stained using the following sequence of steps, where slides were: (1) deparaffinized and hydrated to distilled water, (2) stained in a filtered hematoxylin solution for $6 \mathrm{~min}$ and rinsed in running tap water to remove excess stain, (3) quickly dipped in acid alcohol three times and rinsed in running tap water, (4) slowly dipped in ammonia water three to five times and rinsed in running tap water, (5) rinsed in 95\% alcohol, (6) stained in eosin-Y solution for $1 \mathrm{~min}$ and rinsed in $95 \%$ alcohol for two changes, (7) cleared in several changes of xylene, and (8) applied with coverslip with synthetic mounting medium.

We recorded histological skin sections with a SPOT RT digital camera (Diagnostic Instruments, Sterling Heights, MI) that was mounted on a Zeiss Axioplan microscope (Carl Zeiss MicroImaging, Thornwood, NY, USA). We measured tissues that become modified during brood patch development (Jones 1971; 
Rylander et al. 1980; Lea and Klandorf 2002). Using an objective lens with $10 \times$ magnification, we recorded images that we subsequently used to measure (1) epidermis thickness $( \pm 0.1 \mu \mathrm{m})$, (2) connective tissue thickness $( \pm 0.1 \mu \mathrm{m})$, and (3) thickness of the fat (or adipose) tissue $( \pm 0.1 \mu \mathrm{m})$ and musculature $( \pm 0.1 \mu \mathrm{m})$; the latter two components were subsequently combined for analysis (hereafter summarized as other tissue).

We digitally imaged the superficial layer of the dermis, using an objective lens with $40 \times$ magnification, i.e., the top $150 \mu \mathrm{m}$ of a transverse section through the connective tissue, and used these images to measure or index (1) degree of vascularization of the dermis by measuring blood vessel area as defined by Rylander et al. (1980), and (2) degree of leukocyte infiltration of the dermis by counting the number of leukocytes present in the connective tissue within a particular section (hereafter leukocyte count).

We started the imaging at one side of a skin section and recorded every other field of vision up to ten images from each section, which was near the maximum number of images that could be sampled from each slide using the 10× objective lens. We obtained 15-19 images per bird using this method (see Table 2). Using the $40 \times$ objective lens allowed us to sample more than 20 images per bird (i.e., 10 per section), but we used only 20 images to use a consistent number of measurements for each bird in statistical analyses.

We analyzed images of tissues with Scion Image software (Scion Corporation, Frederick, MD, USA). We measured three, $500-\mu \mathrm{m}$-long transects perpendicular to the plane of the epidermis in each image and used the mean thickness of these transects within each image as our sampling unit. We used mean thickness from the three transects to reduce variation in thickness of skin tissues due to possible skewed angles of cutting when we sectioned the tissue samples. We measured blood vessel area by first tracing the circumference of each blood vessel, then calculating the cross-sectional area of each blood vessel from the tracing, and finally adding the cross-sectional areas of all blood vessels to obtain the total blood vessel area. We counted number of leukocytes in each image obtained using the $40 \times$ objective lens.

\section{Statistical analysis}

We used mixed models for our three analyses (Littell et al. 1996) of tissue thickness, blood vessel area, and leukocyte count. All three models included species, sex, and the sex $\times$ species interaction as explanatory fixed effects and individual birds as an explanatory random effect (PROC MIXED; Wright 1998; SAS Institute 1999; see also Littell et al. 1996). Including the sex $\times$ species interaction allowed a direct test of our hypothesis that brood patch histology differed between the two species. Although we collected paired geese, our analyses were not pair-wise contrasts because we had no a priori reason to expect variation due to pair number (1-5) to be biologically meaningful; for our analyses, we assumed pair members were unrelated individuals. We determined final models using backward, stepwise variable selection (cf. Agresti 1996). If mixed models detected significant interactions in our analyses, we kept the interactions in the models and used least-square means (LSMEANS; SAS Institute 1999) to test for effects of species or sex. Our residual error term in all analyses was image within individual bird $(n=15-20$; Table 2$)$.

We used the solution for random effects (cf. Littell et al. 1996; cf. SAS Institute 1999) to examine if any individual consistently deviated from others of the same sex within each species. Here, we report only individuals that differed from others of the same sex within each species in two of three analyses (tissue thickness, blood vessel area, or leukocyte count). We assumed that individual variation in one of these analyses could occur due to random chance. This test is based on mixed model solutions, using an empirical, best linear unbiased estimator of means, which are then compared by likelihood ratios using the E-statistic ( $t$ test; see computations in Littell et al. 1996; SAS Institute 1999). Means are compared and inferences drawn based on logical, a priori comparisons; we only (1) compared males and females for a given variable within each species; and (2) compared species for a given variable within each sex. All other comparisons provided by the software, for example male snow geese versus female Ross's geese, were excluded in our analyses.

We used a multivariate analysis to compare the thickness of the epidermis, connective tissue and other tissues between sexes in PROC MIXED (Wright 1998; SAS Institute 1999), by examining interactions between tissue and the explanatory variables sex and species, with the thickness of each tissue as the response variable. Following Wright (1998), we used the two-way interaction, sex $\times$ tissue (Num $d f=2$ ) to test for effects of sex and the three-way interaction, sex $\times$ species $\times$ tissue (Num $d f=2$ ) to test for effects of species. In this analysis, bird was nested within the three-way interaction. We used a Type 3 sum of square test of fixed effects ( $F$ test; Littell et al. 1996; SAS Institute 1999) to determine whether tissue thickness (hereafter overall thickness) differed between sexes and/or species. If the $F$ test reported significant differences in overall thickness, we subsequently used a Type 3 sum of square test of simple effects ( $t$ test) for effects of sex and species, and report $t$ values (Littell et al. 1996; SAS Institute 1999) for differences in thicknesses of the epidermis, connective tissue, and other tissue. Here, we only used a priori, meaningful comparisons; we only (1) compared males and females for a given tissue within each species; and (2) compared species for a given tissue within each sex. All other comparisons provided by the software were meaningless and thus were excluded in our analysis, for example connective tissue thickness of male snow geese versus epidermis thickness of female Ross's geese. We used two mixed linear models in PROC MIXED to 
compare blood vessel area and leukocyte count between sexes and species. For these analyses, bird was nested within the sex $\times$ species interaction.

\section{Results}

Final models

The final model for skin thickness included the species $x$ sex $\times$ tissue interaction $\left(F_{2,45}=15.2, P<0.001\right)$ and the final model for blood vessel area included the species $\times$ sex interaction $\left(F_{1,14}=26.4, P=0.002\right)$. In both these models, effects of sex were significant but dependent on species. The final model for leukocyte count included species $\left(F_{1,14}=4.76, P=0.030\right)$ and sex $\left(F_{1,14}=5.38\right.$, $P=0.035)$ but the species $\times$ sex interaction was not significant $\left(F_{1,14}=3.51, P=0.082\right)$. Thus, leukocyte count differed between sexes and species and effects of these variables were independent of each other.

\section{Sex comparisons in snow geese}

Connective tissue thickness $(t=5.45, d f=45, P<0.001)$ was greater and other tissue thickness $(t=-5.90, d f=45$, $P<0.001)$ was lower for females as compared to males (Table 1). Epidermis thickness was similar between the sexes $(t=0.39, d f=45, P=0.702)$. Females had on average, 38.9 times larger blood vessel areas than males $(t=7.12, d f=14, P<0.001$; see Table 1$)$. Females had 4.2 times higher leukocyte counts than males $(t=3.05$, $d f=14, P=0.009$; see Table 1). Figure 1 shows a section through the skin in the brood patch of a female snow goose (Fig. 1a) and contrasts it with a section through the skin of the equivalent abdominal region of a male snow goose (Fig. 1b). We observed no individual variation in brood patch development within sexes of snow geese (see also Table 2) for more than one of three variables measured.

\section{Sex comparisons in Ross's geese}

Thickness of epidermis $(t=-0.01, d f=45, P=0.993)$, connective tissue thickness ( $t=0.43, d f=45, P=0.667)$, and other tissues $(t=-0.43, d f=45, P=0.993)$ were similar between sexes (Table 1). Blood vessel area $(t=0.51, d f=14, P=0.618)$ and leukocyte count were similar between sexes $(t=0.68, d f=14, P=0.508)$. Figure 2 shows a section through the skin of abdominal regions representative of four of five Ross's goose females (Fig. 2a) and all five male Ross's geese (Fig. 2b). Female \#5 differed markedly from the other females (see Fig. 3); she had the thickest connective tissue $(t=6.13$, $P<0.001)$, the thinnest other tissue $(t=-6.28$, $P<0.001)$, and the highest leukocyte count of all females $(t=6.58, P<0.001)$ (Table 2).

\section{Interspecific comparisons within sexes}

Female snow geese had thicker connective tissue $(t=-7.68, P<0.001)$ and thinner other tissues $(t=7.98$, $P<0.001)$ than female Ross's geese; thickness of epidermis was similar between females of the two species $(t=-0.36, P=0.718)$ (Table 1). Female snow geese had a larger blood vessel area $(t=-7.94, P<0.001)$ than female Ross's geese (Table 1). Female snow geese had a higher leukocyte count $(t=-3.01, P=0.009)$ than female Ross's geese (Table 1). Thicknesses of all three tissues, blood vessel area, and leukocyte counts were similar between males of the two species $(P>0.05)$.

\section{Discussion}

Final models for histological measurements

We detected significant species $\times$ interactions, indicating that the effects of sex on brood patch histology generally differed between species. In general, brood patch histology differed between sexes of snow geese but not between sexes of Ross's geese. Brood patch histology generally differed between female snow geese and Ross's geese, but the histology of the equivalent region in males did not differ between snow geese and Ross's geese.

Skin histology in snow geese

We found histological modifications of the brood patch skin in all five female snow geese (Fig. 1a), relative to

Table 1 Least-square mean percentage thicknesses ( $\%$ of $500 \mu \mathrm{m}$ transect) ( \pm standard error) of three skin tissues, blood vessel area $\left(\mu \mathrm{m}^{2}\right)$, and leukocyte count (cells/frame) for brood patch regions of five pairs of lesser snow geese and five pairs of Ross's geese collected at Karrak Lake, Nunavut, Canada in 1999

\begin{tabular}{|c|c|c|c|c|}
\hline \multirow[t]{2}{*}{ Skin features } & \multicolumn{2}{|c|}{ Lesser snow geese } & \multicolumn{2}{|l|}{ Ross's geese } \\
\hline & Females $(n=5)$ & Males $(n=5)$ & Females $(n=5)$ & Males $(n=5)$ \\
\hline Epidermis thickness $(\%)$ & $5.4 \pm 5.2$ & $2.2 \pm 5.2$ & $2.8 \pm 5.2$ & $2.8 \pm 5.2$ \\
\hline Connective tissue thickness $(\%)$ & $78.6 \pm 5.2$ & $35.3 \pm 5.2$ & $22.8 \pm 5.2$ & $19.7 \pm 5.2$ \\
\hline Other tissue thickness $(\%)$ & $16.0 \pm 5.2$ & $62.5 \pm 5.2$ & $74.3 \pm 5.2$ & $77.5 \pm 5.2$ \\
\hline Blood vessel area $\left(\mu \mathrm{m}^{2}\right)$ & $2637.2 \pm 220.5$ & $67.4 \pm 286.0$ & $200.9 \pm 213.4$ & $46.9 \pm 213.5$ \\
\hline Leukocyte count (cells/frame) & $106.0 \pm 16.1$ & $25.7 \pm 20.8$ & $37.8 \pm 16.0$ & $22.5 \pm 16.0$ \\
\hline
\end{tabular}

See text for descriptions of tissues and statistical tests between sexes within each species 
Table 2 Means (mean \pm SE) from brood patch regions of five pairs of lesser snow geese and five pairs of Ross's geese, collected at Karrak Lake, Nunavut, Canada, 1999

\begin{tabular}{|c|c|c|c|c|c|}
\hline $\begin{array}{l}\text { Bird no. }(n=\text { no. } \\
\text { images obtained for } \\
\text { tissue thicknesses })\end{array}$ & $\begin{array}{l}\text { Dermal connective } \\
\text { tissue thickness }(\mu \mathrm{m})\end{array}$ & $\begin{array}{l}\text { Epidermis } \\
\text { thickness }(\mu \mathrm{m})\end{array}$ & $\begin{array}{l}\text { Other tissue } \\
\text { thickness }(\mu \mathrm{m})\end{array}$ & $\begin{array}{l}\text { Blood vessel } \\
\text { area }\left(\mu \mathrm{m}^{2}\right)^{\mathrm{a}}\end{array}$ & 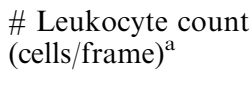 \\
\hline \multicolumn{6}{|l|}{ Lesser snow Geese } \\
\hline Male \#1 $(n=19)$ & $252.0 \pm 135.2$ & $10.3 \pm 1.8$ & $237.7 \pm 135.4$ & $112.2 \pm 232.2$ & $41.1 \pm 32.6$ \\
\hline Male \#2 $(n=16)$ & $104.6 \pm 2.5$ & $10.4 \pm 1.8$ & $385.1 \pm 0.7$ & $104.1 \pm 219.4$ & $39.3 \pm 27.8$ \\
\hline Male \#3 $(n=17)$ & $147.4 \pm 93.3$ & $12.1 \pm 2.1$ & $340.5 \pm 93.6$ & $25.5 \pm 70.2$ & $31.1 \pm 15.5$ \\
\hline Male \#4 $(n=20)$ & $189.3 \pm 99.7$ & $11.8 \pm 1.9$ & $298.9 \pm 99.6$ & $20.6 \pm 61.8$ & $13.7 \pm 11.4$ \\
\hline Male \#5 $(n=16)$ & $135.0 \pm 75.6$ & $13.4 \pm 2.6$ & $364.3 \pm 89.0$ & $77.3 \pm 61.2$ & $24.2 \pm 13.5$ \\
\hline Female \#1 $(n=20)$ & $364.6 \pm 111.9$ & $22.6 \pm 8.1$ & $112.7 \pm 114.6$ & $2467.5 \pm 1131.8$ & $109.3 \pm 45.0$ \\
\hline Female \#2 $(n=19)$ & $415.1 \pm 70.8$ & $22.6 \pm 6.5$ & $62.3 \pm 73.1$ & $3749.3 \pm 1059.1$ & $108.7 \pm 38.1$ \\
\hline Female \#3 $(n=20)$ & $462.0 \pm 6.2$ & $38.0 \pm 6.2$ & $0.0 \pm 0.0$ & $1429.1 \pm 890.0$ & $101.1 \pm 25.1$ \\
\hline Female \#4 $(n=20)$ & $309.1 \pm 43.9$ & $26.6 \pm 7.2$ & $167.8 \pm 52.9$ & $3275.2 \pm 1473.3$ & $75.3 \pm 23.6$ \\
\hline Female \#5 $(n=17)$ & $423.3 \pm 75.2$ & $25.0 \pm 10.0$ & $51.7 \pm 77.2$ & $2264.7 \pm 1415.2$ & $135.7 \pm 43.6$ \\
\hline \multicolumn{6}{|l|}{ Ross's geese } \\
\hline Male \#1 $(n=17)$ & $119.7 \pm 81.1$ & $16.3 \pm 4.1$ & $37.0 \pm 83.3$ & $20.3 \pm 36.9$ & $18.4 \pm 11.7$ \\
\hline Male \#2 $(n=18)$ & $87.1 \pm 45.8$ & $13.2 \pm 2.5$ & $399.7 \pm 43.9$ & $24.9 \pm 46.0$ & $12.1 \pm 11.8$ \\
\hline Male \#3 $(n=16)$ & $96.4 \pm 50.6$ & $15.4 \pm 3.2$ & $388.1 \pm 52.1$ & $53.2 \pm 99.7$ & $39.9 \pm 24.0$ \\
\hline Male \#4 $(n=17)$ & $111.4 \pm 89.2$ & $11.8 \pm 3.0$ & $370.7 \pm 90.2$ & $128.3 \pm 540.8$ & $25.6 \pm 27.0$ \\
\hline Male \#5 (n=17) & $74.8 \pm 23.1$ & $13.2 \pm 3.7$ & $411.9 \pm 24.0$ & $8.0 \pm 21.0$ & $16.5 \pm 11.6$ \\
\hline Female \#1 $(n=19)$ & $81.1 \pm 23.7$ & $13.9 \pm 2.4$ & $397.2 \pm 36.8$ & $165.7 \pm 390.3$ & $14.0 \pm 13.4$ \\
\hline Female \#2 $(n=17)$ & $80.2 \pm 45.5$ & $11.5 \pm 2.7$ & $408.3 \pm 46.1$ & $125.7 \pm 159.4$ & $13.7 \pm 13.3$ \\
\hline Female \#3 $(n=15)$ & $53.4 \pm 14.4$ & $11.3 \pm 2.6$ & $435.3 \pm 14.6$ & $6.9 \pm 5.5$ & $4.4 \pm 4.6$ \\
\hline Female \#4 $(n=20)$ & $50.6 \pm 19.8$ & $11.6 \pm 2.8$ & $437.5 \pm 21.0$ & $104.8 \pm 305.4$ & $9.7 \pm 14.7$ \\
\hline Female \#5 $(n=18)$ & $303.0 \pm 197.1$ & $19.7 \pm 8.3$ & $177.3 \pm 202.8$ & $601.4 \pm 336.9$ & $147.6 \pm 17.4$ \\
\hline
\end{tabular}

See text for the description of tissues and statistical tests for differences between birds within each sex

${ }^{a} n$ were always 20 images/bird for blood vessel area and leukocyte count

skin from equivalent abdominal regions of males (Fig. 1b). Female snow geese had: (1) thickened connective tissues, (2) an increased blood vessel area, and (3) an increased number of leukocytes in the connective tissue, as described also by Jones (1971), Gill (1995), and Lea and Klandorf (2002). Accordingly, we conclude that the five female snow geese in our study had fully developed brood patches to enhance heat transfer to eggs. The only difference between brood patches of snow geese and those of other birds is that feathers are plucked for brood patch development by female snow geese instead of being shed by a hormone-induced process in other birds (Hanson 1959; Jones 1971; Cole 1979). Our analysis for snow geese clearly refutes

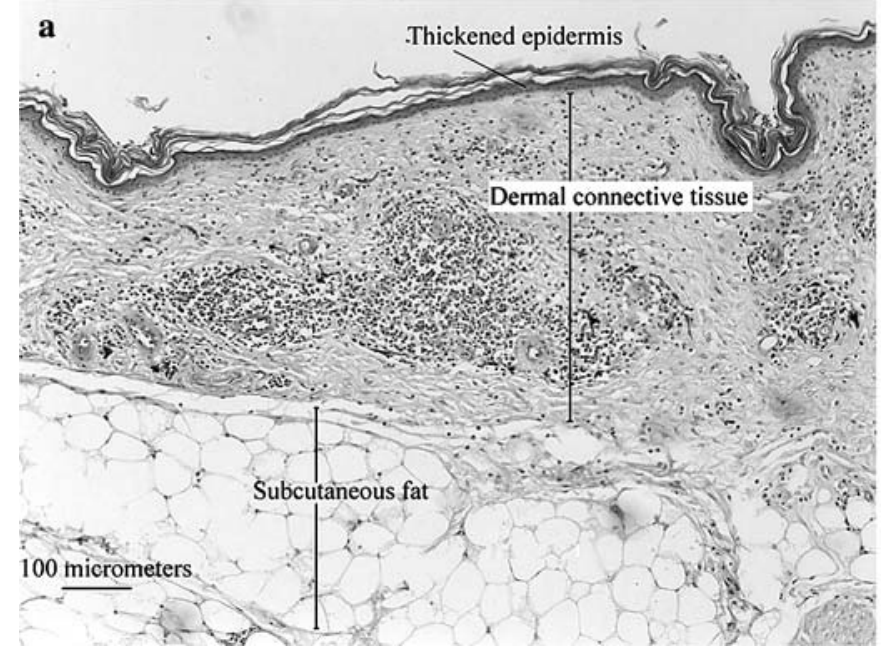

Fig. 1 a Transverse sections through the skin of the brood patch region of lesser snow geese stained with eosin-hematoxylin. Female snow goose \#2: Note the thick layer of dermal connective tissue in the dermis directly underneath the epidermis. Note also the lumina of blood vessels (white spots in dermal connective tissue) and the

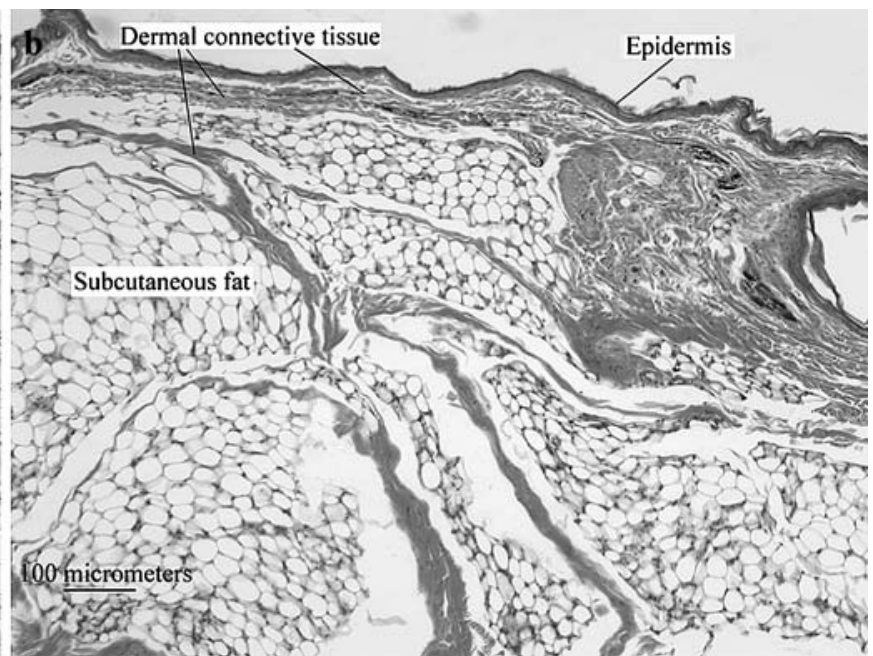

leukocytes (dark spots) embedded in the dermal connective tissue (see also inset in Fig. 3). b Male snow goose \# 5: Note the relatively thin layer of dermal connective tissue in the dermis directly underneath the epidermis 


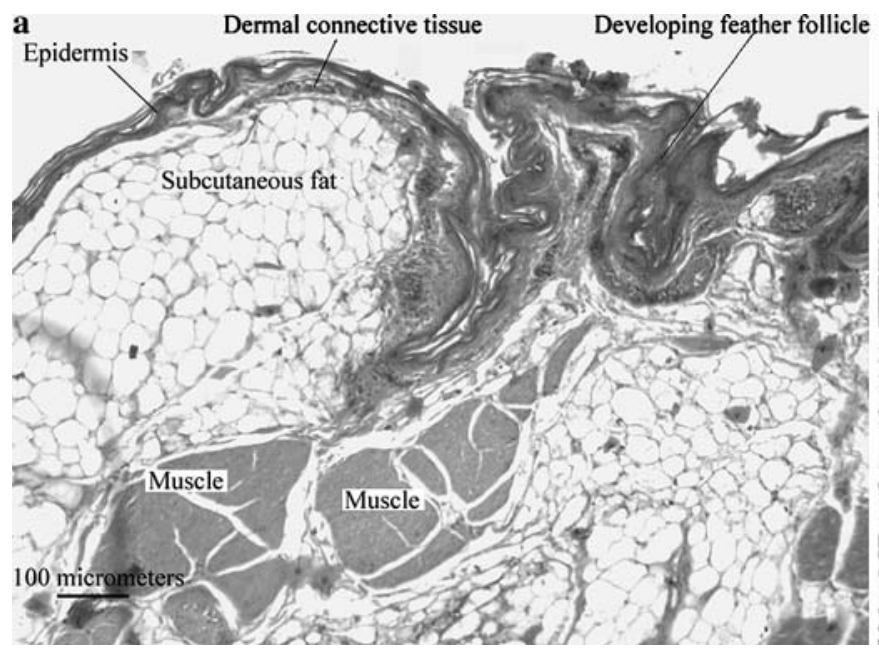

Fig. 2 a Transverse sections through the skin of the brood patch region of Ross's geese stained with eosin-hematoxylin. Female Ross's goose \#2: Note the relatively thin dermal connective tissue layer in the dermis directly underneath the epidermis. Four of five female Ross's geese had brood patches similar to this one; one

previous broad categorical statements that waterfowl do not fully develop brood patches (see Bailey 1952; Jones 1971; Dorst 1975; Gill 1995; Lea and Klandorf 2002).

\section{Skin histology in Ross's geese}

We detected variable brood patch development in female Ross's geese; female \#5 (Fig. 3) had a fully developed brood patch similar to those of the snow geese that we analyzed. Thus, our results suggest that Ross's geese possibly are similar to alcids, wherein some individuals fully develop brood patches and others do so to a lesser degree or not at all, i.e., have incomplete brood patch development (Manuwal 1974; McFarlane Tranquilla et al. 2003).

Why does brood patch development differ between snow geese and Ross's geese?

A fully developed brood patch may shorten the incubation period, but may not be necessary to incubate a clutch successfully (McFarlane Tranquilla et al. 2003). We hypothesize that, because of their smaller size and concomitant lower fasting endurance compared to those of snow geese (Skutch 1962; Afton 1980; Afton and Paulus 1992), at least some Ross's geese benefit by either not fully developing brood patches or by maintaining them for shorter periods during incubation than snow geese.

Interestingly, the size of the defeathered ventral area is negatively related to prolactin levels in Ross's geese, but not in snow geese (Jónsson et al. 2006). This difference is consistent with the hypothesis that Ross's

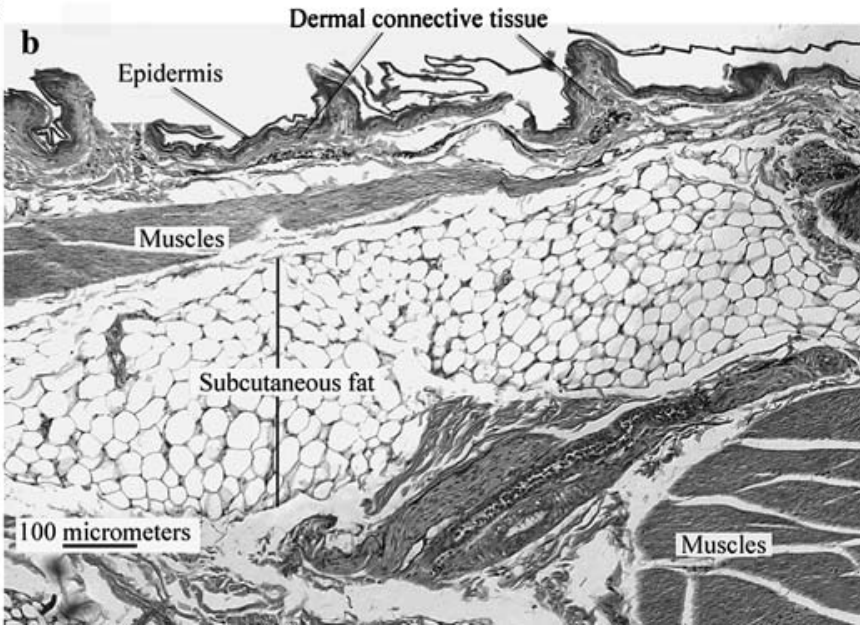

female Ross's goose (\#5) had a brood patch that was similar to that of snow geese and is shown in Fig. 3. b Male Ross's goose \#3: Note the relatively thin layer of dermal connective tissue in the dermis directly underneath the epidermis, and how similar the male is to the female in a

geese are more adversely affected by heat loss through the brood patch region than snow geese because of their smaller size (Brummermann and Reinertsen 1991; Jónsson et al. 2006). Thus, greater susceptibility to cold and wind may select against full brood patch development in most Ross's geese females. A critical and

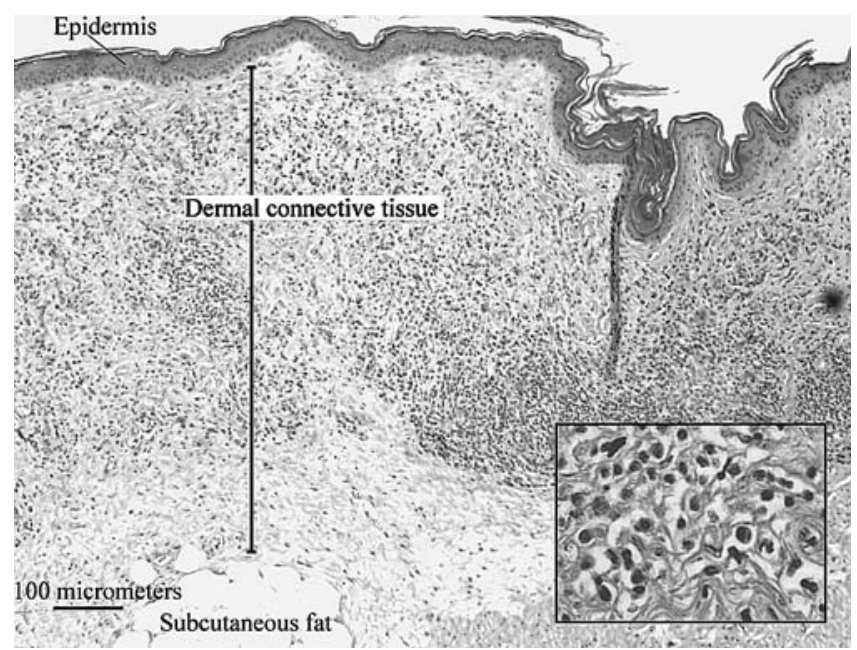

Fig. 3 A transverse section of brood patch region from female Ross's goose \#5 stained with eosin-hematoxylin. Note the similarities with the snow goose brood patch in Fig. 1a, and compare with the section of the skin through the brood patch of another female Ross's goose in Fig. 2a. Note: (1) the thick dermal connective tissue of the dermis directly underneath the epidermis, (2) the lumina of blood vessels (white), and (3) the leukocytes (dark spots in connective tissue) embedded in the dermal connective tissue (see also Fig. 1a). Inset was imaged using the $40 \times$ objective lens and shows the dermal connective tissue, stained with eosin-hematoxylin, and shows lumina of blood vessels (white spots in connective tissue) and leukocytes embedded in the dermal connective tissue (dark spheres) 
reasonable assumption here is that snow geese and Ross's geese are exposed to the same microclimate during nesting, have similar shape and morphology, spend similar amount of time in water (which we believe is reasonable for Karrak Lake; A. D. Afton, personal observations), and possess the same behaviors and physiological adaptations for thermoregulation and thus, their ability to tolerate heat loss differs only as predicted by their different body sizes.

Why is brood patch development variable in female Ross's geese?

We propose three hypotheses to explain the observed variable brood patch development in female Ross's geese. All three hypotheses posit that the need for a fully developed brood patch in Ross's geese is mitigated by their particular physiology for at least a part of the incubation period. During late incubation, Ross's goose embryos may need relatively less thermal protection than those of snow geese because they are relatively more developed at hatch, as evidenced by their relatively larger pectoralis muscles, larger gizzards, and lower water contents in tissues (Slattery and Alisauskas 1995). Ross's goose embryos also grow faster and generate more metabolic heat during early incubation than snow goose embryos (Craig 2000); thus, Ross's goose embryos may be relatively less dependent on constant heat transfer from their incubating mothers.

Our first hypothesis posits that brood patch development is phenotypically fixed by species; female snow geese fully develop brood patches, whereas female Ross's geese have incomplete brood patches. Although analysis of morphometric measurements did not indicate that any specimens were hybrids, Ross's goose female \#5 nevertheless could have been of mixed snow goose $x$ Ross's goose ancestry (i.e., F2 or F3 offspring of hybrids). Future tests of this hypothesis will require the identification of genetic relationships of specimens when making interspecific comparisons regarding brood patch development.

Our second hypothesis posits that (1) females of both species fully developed brood patches, but that most Ross's geese reduced their brood patches earlier in the incubation period than snow geese, and (2) Ross's geese can incubate successfully without fully developed brood patches during late incubation. Under this hypothesis, most female Ross's geese reduce their brood patches during late incubation, whereas snow geese reduce their brood patches only after eggs hatch. Thus, female \#5 could have retained her brood patch relatively longer than the other four female Ross's geese. Brood patches are generally developed 5-7 days before the onset of incubation (Lea and Klandorf 2002; McFarlane Tranquilla et al. 2003), and it is conceivable that they can regress just as rapidly. This hypothesis could be tested by analyzing skin samples from specimens collected throughout the incubation period.
Our third hypothesis posits that variable brood patch development in Ross's geese is the result of a natural polymorphism within this species (hereafter called Polymorphism Hypothesis). Morphological and physiological characters frequently vary within populations, and we assume that the same would hold true for the expression of brood patches, as is the case in Cassin's auklets (Manuwal 1974). We documented individual variability in skin thickness, blood vessel area, and leukocyte count in both species (see Table 2), which indicates possible individual variation in the ability to fully develop brood patches (see McFarlane Tranquilla et al. 2003). Such a polymorphic brood patch development could be at least partly under genetic control and partly influenced by biological factors, such as the particular physiology of a species, parental age, nest initiation date, body condition, and breeding experience. All these factors are known to influence the reproductive success of geese (Ankney and MacInnes 1978; Cooke et al. 1995; Lepage et al. 2000). Environmental conditions, such as weather and food availability, may represent the major selective regime for this polymorphism. In years of harsh weather or low food abundance, Ross's geese that do not develop brood patches may be at a selective advantage, whereas in years of milder weather and abundant food, Ross's geese that develop brood patches fully may be more successful. Alternatively, this polymorphism also could result from frequent interbreeding between snow geese and Ross's geese (Weckstein et al. 2002) and, hence, the introductions of genes for brood patch development from snow geese into Ross's geese populations as per our first hypothesis. In order to test the Polymorphism Hypothesis, a long-term study of the occurrence of brood patches within the two goose species is needed, using a larger sample along with genetic analysis of specimens. Furthermore, such a study should carefully document incubation stage, female body condition, female survival, and subsequent survival of resulting goslings, to determine if fully developed brood patches lead to relatively more viable offspring.

\section{Do other Anseriformes develop brood patches?}

Average incubation periods of geese are positively related to body size (Owen and Black 1990; Afton and Paulus 1992, Fig. 4). Snow geese, however, have a shorter incubation period than that predicted by their body weight, and this trend also is true for Ross's geese and greater snow geese (C. c. atlanticus; Fig. 4), suggesting that there has been a stronger selection for short incubation periods in these Arctic-nesting species as compared to other geese. Arctic-nesting waterfowl should benefit from maximized efficiency of heat transfer provided by fully developed brood patches because they (1) often are exposed to low temperatures and high wind velocities, which cool eggs during incubation recesses (Gloutney et al. 1999), (2) nest in habitats where nesting materials, that could be used for thermal insulation, 
Fig. 4 The relationship between body mass and incubation period in Northern Hemisphere geese (after Cramp and Simmons 1978; Afton and Paulus 1992; see also Owen and Black (1990)

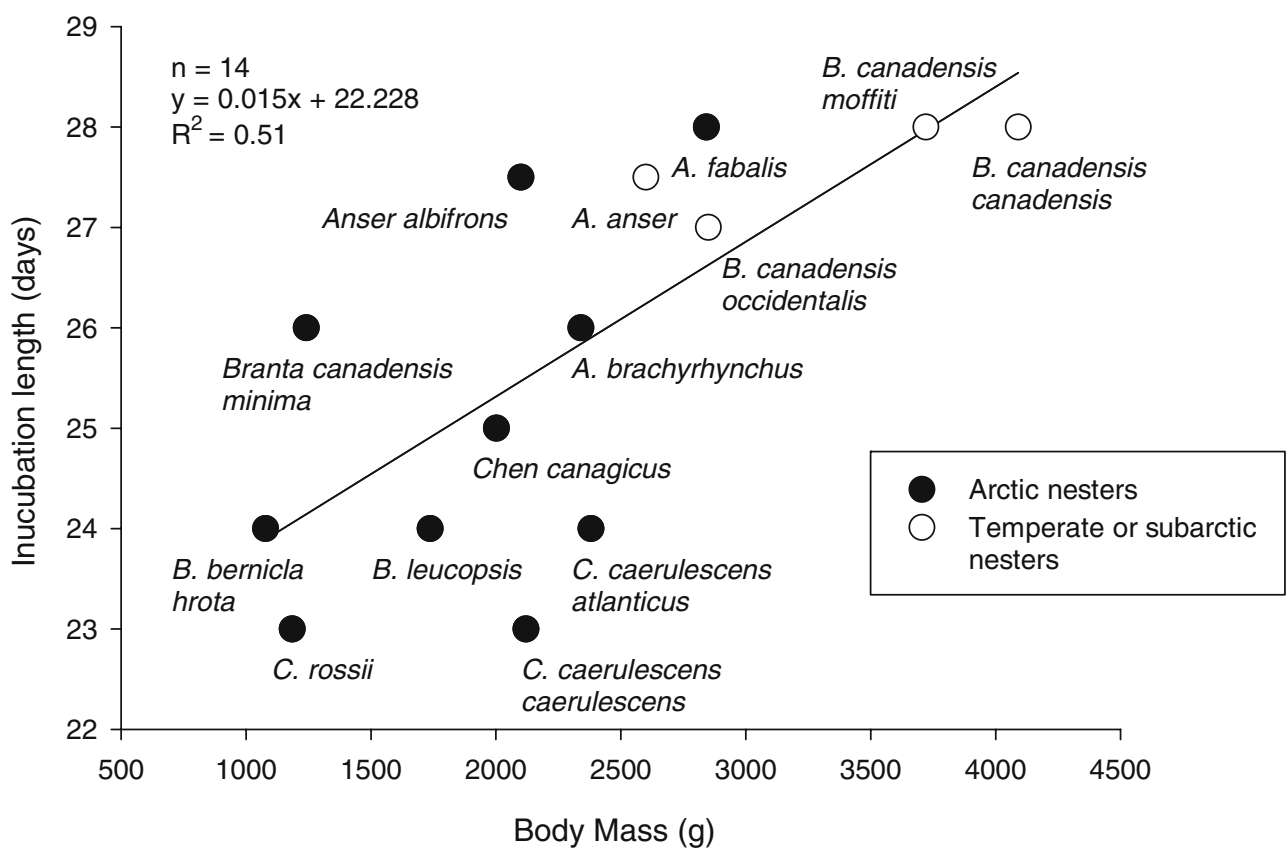

often are scarce (McCracken et al. 1997), and (3) practice uniparental incubation (Afton and Paulus 1992), which precludes them from alternating incubation sessions between pair members, as reported for whistling ducks (Rylander et al. 1980). Geese and whistling ducks also differ in that female geese remove feathers from their brood patches, whereas whistling ducks incubate with fully feathered brood patches (Rylander et al. 1980; Afton and Paulus 1992). Interestingly, whistling ducks and geese are classified among the most ancestral groups of waterfowl (Livezey 1986), which raises the question whether fully developed brood patches are an ancestral trait in the family. This question perhaps could be answered by studying brood patch development in more derived groups, such as dabbling ducks (Anatini), diving ducks (Aythiini), eiders (Somaterini), and seaducks (Mergini). Species within these groups nest in a broad range of climatic conditions and, thus, may vary in brood patch development. An investigation of brood patch development in Magpie geese (Anseranas semipalmata) would be particularly interesting because (1) they breed in pairs and trios; trios are almost always comprised of one male and two females, and (2) males participate in incubation duties (Kear 1973; see also Afton and Paulus 1992).

\section{Conclusion}

We documented that all five female snow geese and one of five female Ross's geese in our sample fully developed brood patches. We argue that, because of their smaller size and concomitant lower fasting endurance compared to those of snow geese (Skutch 1962; Afton 1980; Afton and Paulus 1992), at least some Ross's geese benefit either by not fully developing brood patches or by maintaining them for shorter periods during incubation than snow geese. We agree with McFarlane Tranquilla et al. (2003) that future studies should examine the effects of individual variation on brood patch development and encourage further tests of the three hypotheses proposed here, as well as comparative histological studies of brood patch development among other waterfowl species. Future studies should then determine when brood patches are developed and regressed in different waterfowl species by collecting tissue samples at different incubation stages. Particularly, measurements of energy consumption by females during different stages of brood patch development would provide important tests of the hypotheses presented above.

Acknowledgements Our study received financial and logistical support from: Louisiana Department of Wildlife and Fisheries, Canadian Wildlife Service, Arctic Goose Joint Venture, Delta Waterfowl Foundation; and United States Geological SurveyLouisiana Cooperative Fish and Wildlife Research Unit, School of Veterinary Medicine (SVMLSU), School of Renewable Natural Resources, and the Graduate School at Louisiana State University (LSU). We thank Richard E. Olsen for assistance with collecting geese at Karrak Lake. Dr. Cheryl Crowder of the Department of Pathobiological Sciences, SVMLSU, prepared the histological slides used in this study. We are especially grateful to Greg McCormick and Olga Borkhsenius at the Microscopy Center at SVMLSU for their assistance with the microscopy work. David C. Blouin and E. Barry Moser of the Department of Experimental Statistics at LSU provided valuable statistical advice. We thank Michael J. Anteau, Michael D. Chamberlain, Michael D. Kaller, and three anonymous reviewers for helpful comments on earlier drafts of this manuscript. We collected geese at Karrak Lake under Canadian Wildlife Service permit \# NUN-SCI-99-19 and Louisiana State University Institutional Animal Care and Use Permit \#A94-16. 


\section{References}

Afton AD (1980) Factors affecting incubation rhythms of northern shovelers. Condor 82:132-137

Afton AD, Paulus SL (1992) Incubation and brood care. In: Batt BDJ (ed) Ecology and management of breeding waterfowl. University of Minnesota Press, Minneapolis, pp 62-108

Agresti A (1996) An introduction to categorical data analysis. John Wiley, New York

Alisauskas RT, Boyd H (1994) Previously unrecorded colonies of Ross's and lesser snow geese in the Queen Maud Gulf bird sanctuary. Arctic 47:69-73

Ankney CD, MacInnes CD (1978) Nutrient reserves and reproductive performance of female lesser snow geese. Auk 95:459-471

Bailey RE (1952) The incubation patch of passerine birds. Condor 54:121-136

Batt BDJ (ed) (1997) Arctic ecosystems in peril: report of the Arctic Goose Habitat Working Group. Arctic goose joint venture special publication. US Fish and Wildlife Service, Washington, DC, and Canadian Wildlife Service, Ottawa

Brummermann M, Reinertsen RE (1991) Adaptation of homeostatic thermoregulation: comparison of incubating and nonincubating Bantam hens. J Comp Physiol B 161:133-140

Calder WA III (1996) Size, function and life history. 2nd edn. Dover Publications, Mineola

Cole JM (1979) Canada goose down pulling behavior and some functional aspects of Canada goose nest down. MS Thesis, University of Minnesota

Cooke F, Rockwell RF, Lank DB (1995) The snow geese of LaPerouse Bay. Natural selection in the wild. Oxford University Press, Oxford

Cramp S, Simmons KEL (1978) Handbook of the birds of Europe, the Middle East, and North Africa. Birds of the Western Palearctic. Oxford University Press, Oxford

Craig LM (2000) Comparative incubation ecology of Ross's and lesser snow geese at Karrak Lake, Nunavut. MSc Thesis. University of Saskatchewan

Dorst JD (1975) The life of birds. Columbia University Press, New York

Drent R (1975) Incubation. In: Farner DS, King JR, Parkes KC (eds) Avian biology, vol 5. Academic, New York, pp 333-419

Dzubin A, Cooch EG (1992) Measurements of geese: general field methods. California Waterfowl Association, Sacramento, CA, USA

Gill FB (1995) Ornithology. 2nd edn. WH Freeman and Company, New York

Gloutney ML, Alisauskas RT, Hobson KA, Afton AD (1999) Use of supplemental food by breeding Ross's geese and lesser snow geese: evidence for variable anorexia. Auk 116:97-108

Gloutney ML, Alisauskas RT, Afton AD, Slattery SM (2001) Foraging time and dietary intake by breeding Ross's and lesser snow geese. Oecologia 127:470-478

Hanson HC (1959) The incubation patch of wild geese: its recognition and significance. Arctic 12:139-150

Jones RE (1971) The incubation patch of birds. Biol Rev 46:315-339

Jónsson JE, Afton AD, Alisauskas RT, Bluhm CK, El Halawani ME (2006) Ecological and physiological factors affecting brood patch area and prolactin levels in arctic-nesting geese. Auk (in press)

Kear J (1973) The magpie goose in captivity. Int Zoo Yrbk 13:28-32

Kendeigh SC (1970) Energy requirements for existence in relation to size of bird. Condor 72:60-65

Krebs JR, Davies NB (1993) An introduction to behavioral ecology. 3rd edn. Blackwell, Oxford

Lea RW, Klandorf H (2002) The brood patch. In: Deeming DC (ed) Avian incubation. Oxford ornithology series. Oxford University Press, Oxford, pp 100-118
Lepage D, Gauthier G, Menu S (2000) Reproductive consequences of egg-laying decisions in snow geese. J Anim Ecol 69:414-427

Littell RC, Milliken GA, Stroup WW, Wolfinger RD (1996) SAS system for mixed models. SAS Institute, Cary

Livezey BC (1986) A phylogenetic analysis of recent anseriform genera using morphological characters. Auk 103:737-754

MacInnes CD, Misra RK, Prevett JP (1989) Differences in growth parameters of Ross's geese and snow geese: evidence from hybrids. Can J Zool 67:286-290

Manuwal D (1974) The incubation patches of Cassin's auklet. Condor 76:481-484

McCracken KG, Afton AD, Alisauskas RT (1997) Nest morphology and body size of Ross's geese and lesser snow geese. Auk 114:610-618

Mcfarlane Tranquilla LA, Bradley RW, Lank DB, Williams TD, Lougheed LW, Cooke F (2003) The reliability of brood patches in assessing reproductive status in the marbled murrelet: words of caution. Waterbirds 26:108-118

McLandress MR (1983) Temporal changes in habitat selection and nest spacing in a colony of Ross's and lesser snow geese. Auk 100:335-343

Midtgård U (1989) Circulatory adaptations to cold in birds. In: Bech C, Reinertsen RE (eds) Physiology of cold adaptation in birds. Plenum, New York, pp 211-222

Midtgård U, Sejrsen P, Johansen K (1985) Blood flow in the brood patch of Bantam hens: evidence of cold vasodilation. J Comp Physiol B 155:703-709

Owen M, Black J (1990) Waterfowl ecology. Blackie Publishers, Glasgow

Payne RB (1966) Absence of brood patch in Cassin auklets. Condor 68:209-210

Poussart C, Larochelle J, Gauthier G (2000) The thermal regime of eggs during laying and incubation in greater snow geese. Condor 102:292-300

Reinertsen RE, Haftorn S (1986) Different metabolic strategies of northern birds for nocturnal survival. J Comp Physiol B 156:655-663

Ryder JP (1972) Biology of nesting Ross's geese. Ardea 60:185-215

Rylander MK, Bolen EG, McCamant RE (1980) Evidence of incubation patches in whistling ducks. Southwest Nat 25:126128

SAS Institute (1999) SAS/STAT user's guide. Version 8.0. SAS Institute, Cary

Schmidt-Nielsen K (1997) Animal physiology. Adaptation and environment. 5th edn. Cambridge University Press, Cambridge

Skutch AF (1962) The constancy of incubation. Wilson Bull $74: 115-152$

Slattery SM, Alisauskas RT (1995) Egg characteristics and body reserves of neonate Ross's and lesser snow geese. Condor 97:970-984

Thompson SC, Raveling DG (1987) Incubation behavior of emperor geese compared to other geese: interactions of predation, body size and energetics. Auk 104:707-716

Weckstein JD, Afton AD, Zink RM, Alisauskas RT (2002) Hybridization and population subdivision within and between Ross's geese and lesser snow geese: a molecular perspective. Condor 104:432-436

Weller MW (1956) A simple field candler for waterfowl eggs. J Wildl Manage 20:111-113

Welty JC, Baptista L (1988) The life of birds. 4th edn. Saunders College Publishing, Fort Worth

Wiebe KL, Bortolotti GR (1993) Brood patches of American kestrels; an ecological and evolutionary perspective. Ornis Scand 24:197-204

Wright, PS (1998) [ONLINE] Multivariate analysis using the MIXED procedure. In: Proceedings of SAS users group international conference 23, paper 229. SAS Institute Inc. URL: http://www2.sas.com/proceedings/sugi23/Stats/p229.pdf 